the pathogenesis of meningococcal infections, where invasive disease correlates with the lack of meningococcal bactericidal activity ${ }^{2}$ because of the presence of blocking antibody. ${ }^{3}$ Evidence for a similar phenomenon in the case of the gonococcus is supported by the finding that serum resistance, a characteristic of $N$ gonorrhoeae in disseminated disease, ${ }^{4}$ is also related to the presence of blocking antibody. ${ }^{5}$

Our data suggest that the gonococcus may transiently colonise the pharynx without causing complications. Since we cannot distinguish between patients who will spontaneously become culture-negative and those who will develop sequelae, withholding routine treatment does not appear to be warranted. Further studies are needed to define the factors that play a determinant part in the host-gonococcal interaction.

Requests for reprints should be addressed to: Dr Johan Wallin' Department of Dermatology and Venereology, University Hospital, S-75014, Uppsala 14, Sweden.

1 Wiesner, P J, et al, New England fournal of Medicine, 1973, 288, 181.

2 Goldschneider, I, Gotschilich, E, and Artenstein, M S, fournal of Experimental Medicine, 1969, 129, 1307.

${ }^{3}$ McLeod Griffiss, J, and Bertram, M A, fournal of Infectious Diseases, 1977, 136, 733.

4 Schoolnick, G K, Buchanan, T M, and Holmes, K K, fournal of Clinical Investigation, 1976, 58, 1163.

5 McCutchan, J A, et al, in Immunobiology of Neisseria gonorrhoeae, ed F E Young, p 181. Washington, American Society for Microbiology, 1978.

(Accepted 28 March 1979)

Department of Dermatology and Venereology, University Hospital, S-75014 Uppsala 14, Sweden

J WALLIN, MD, associate professor in dermatology and venereology

M S SIEGEL, MD, senior fellow, Division of Infectious Diseases, Department of Medicine, University of Washington, Seattle, Washington, USA

\section{Enterotoxigenic Escherichia coli causing diarrhoea in travellers returning to the United Kingdom}

During the past five years enterotoxigenic strains of Escherichia coli (ETEC) have been one of the most important causes of acute watery diarrhoea in areas of poor hygiene, notably in the tropics. Infants and young children are particularly at risk but adults may also be infected. Investigations in the United States of America and in Sweden suggest that ETEC are not important causes of sporadic diarrhoea in temperate areas of good hygiene. In a study of 61 children with acute diarrhoea in Boston, USA, no evidence was found of infection with ETEC, ${ }^{1}$ and a study of 648 patients with diarrhoea in Sweden $^{2}$ concluded that ETEC were not important causes of diarrhoea. Nevertheless, ETEC are a significant cause of diarrhoea among visitors to tropical areas. Diarrhoea acquired after arrival in Mexico by students from the USA ${ }^{3}$ was due in $72 \%$ of cases to ETEC, and ETEC were found in $11 \%$ of travellers who acquired diarrhoea while abroad or shortly after returning to Sweden. ${ }^{2}$ Because of air transport travellers may return home while still in the acute stage of an infectious diarrhoea acquired abroad. We sought to determine the importance of ETEC as a cause of travellers' diarrhoea in patients returning to the United Kingdom.

\section{Methods, materials, and results}

We studied 55 epidemiologically unrelated patients who developed diarrhoea during or shortly after travel abroad. Six were under 5 years old, two were between 5 and 14, and 47 were over 15 . Fifteen patients had visited the Indian subcontinent, 11 had visited Spain or Portugal, and five had visited North Africa. In all, 21 different countries were represented. A further 50 patients with diarrhoea who had not recently been abroad were studied as a control group. Eleven were under 5 years old, six were between 5 and 14 , and 33 were over 15 . Sixty-two cultures were examined from each group of patients. All the cultures were identified as $E$ coli by biochemical tests and were serotyped with antisera for $O$ groups 1 to 164 and $\mathrm{H}$ antigens 1 to 56 . The $E$ coli strains were tested for the production of heat-stable enterotoxin (ST) by the infant mouse test, and for heat-labile enterotoxin (LT) by the CHO and Y1 tissue culture tests. ${ }^{4}$

ETEC were isolated from six $(11 \%)$ patients who had recently travelled abroad and from one ( $2 \%$ ) patient with no history of recent travel. The seven ETEC strains belonged to seven different $O$ groups. Three strains produced ST only, two produced LT only, and two produced ST and LT. Six of the patients with ETEC were adults and one was a 9-month-old baby (table).

Serotypes of ETEC in sporadic diarrhoea in 55 travellers and 50 non-travellers in England and Wales

\begin{tabular}{|c|c|c|c|}
\hline Serotype & $\begin{array}{c}\text { Enterotoxin } \\
\text { produced }\end{array}$ & Country visited & $\begin{array}{l}\text { Age of } \\
\text { patient }\end{array}$ \\
\hline $\begin{array}{l}\text { O6.H16 } \\
\text { O7.H18 } \\
\text { O20.H11 } \\
\text { O89.H- } \\
\text { O128.H18 } \\
\text { O148.H28 } \\
\text { O? H- }\end{array}$ & $\begin{array}{l}\text { ST + LT } \\
\text { LT } \\
\text { ST } \\
\text { ST } \\
\text { ST } \\
\text { ST + LT } \\
\text { LT }\end{array}$ & $\begin{array}{l}\text { Sierra Leone } \\
\text { India } \\
\text { Not abroad } \\
\text { Middle East } \\
\text { India } \\
\text { Yugoslavia } \\
\text { France }\end{array}$ & $\begin{array}{l}\text { Adult } \\
\text { Adult } \\
\text { Adult } \\
\text { Adult } \\
9 \text { months } \\
\text { Adult } \\
\text { Adult }\end{array}$ \\
\hline
\end{tabular}

\section{Comment}

Although ETEC have caused hospital outbreaks of infantile diarrhoea in Scotland and England, ${ }^{5}$ there is little information about their importance as a cause of sporadic diarrhoea in the community in the UK. Our findings suggest that ETEC are an uncommon cause of indigenous sporadic diarrhoea in the UK but confirm that they may be a significant cause of diarrhoea among travellers returning from abroad. These results closely agree with those of similar studies in Sweden. Laboratory workers investigating travellers' diarrhoea should be aware of the importance of ETEC. If salmonellae and shigellae are not isolated strains of $E$ coli should be sent to the reference laboratory for serotyping and enterotoxin testing.

${ }^{1}$ Echeverria, P, Blacklow, N R, and Smith, D H, Lancet, 1975, 2, 1113.

2 Back, E, Blomberg, S, and Wadstrom, T, Infection, 1977, 5, 2.

${ }^{3}$ Gorbach, S L, et al, New England fournal of Medicine, 1975, 292, 933.

4 Gross, R J, Scotland, S M, and Rowe, B, Lancet, 1978, 1, 629.

5 Rowe, B, et al, fournal of Clinical Pathology, 1978, 31, 217.

(Accepted 20 April 1979)

Division of Enteric Pathogens, Central Public Health Laboratory, London NW9 5HT

R J GROSS, MA, principal microbiologist

SYLVIA M SCOTLAND, PHD, senior microbiologist

B ROWE, MB, MRCPATH, director

\section{$\theta$}

\section{Possible antigenic similarity between pulmonary carcinoma and cysts of Echinococcus granulosus}

Antigenic similarity between parasites and some human carcinomas has been shown serologically. ${ }^{1}$ The cystic intermediate stage of the cestode Echinococcus granulosus results in a chronic infection, known as hydatid disease. The test of choice for the immunodiagnosis of this disease has been the immunoelectrophoresis (IEP) test using as antigen concentrated $E$ granulosus cyst fluid from sheep. ${ }^{2}$ A test is considered positive when the patient's serum causes the precipitation of a band called arc 5, which is easily identified. In addition to this specific band, however, other bands may be precipitated by the sera of hydatidosis patients as well as by the sera of patients with other diseases. ${ }^{3}$ When the serum from a patient suffering from pulmonary carcinoma was tested using $E$ granulosus cyst fluid a broad and intense precipitin band resulted.

\section{Case report}

A 42-year-old man, a farm worker all his life, was admitted to hospital in January 1978 complaining of tiredness, loss of appetite, persistent cough with occasional haemoptysis, and frequent night sweats. He had smoked 20-30 cigarettes a day for 25 years and had had an episode of renal colic in 1974. The results of clinical and laboratory investigations were normal except for a white cell count of $24.3 \times 10^{9} / 1\left(24300 / \mathrm{mm}^{3}\right)$ and an erythrocyte sedimentation rate of $113 \mathrm{~mm}$ in $1 \mathrm{st}$ h. The peripheral blood contained $86 \%$ 